\title{
Revisiting the Land Conversion of the Protected Forest for the Mining Industry in Tumpang Pitu, Banyuwangi
}

\author{
Dimas Bagus Triatmojo* \\ University of Jember, Indonesia
}

Warah Atikah

University of Jember, Indonesia

\author{
Nurul Laili Fadhilah \\ University of Jember, Indonesia
}

\begin{abstract}
Indonesia is a country that has abundant natural resources, both renewable and non-renewable. The wealth of natural resources contained in the motherland can be utilized for the needs and welfare of the people of Indonesia under Article 33 paragraph (3) of the 1945 Constitution. One of the natural resources in Indonesia is forests. The government establishes a forest area as a protected forest area for a benefit that is expected by law. There is a violation of the use of protected forest areas for interests outside the forestry sector, namely the conversion of the function of protected forests used as mining land violations that are contrary to Article 38 Paragraph 4 of Law Number 41 of 1999. Mining business activities have negative impacts as well as positive impacts that arise. Mining will harm environmental conditions that can affect the social life of the community, reducing the environmental quality of the positive impact of the existence of mining business activities in an area will cause changes to the economic level, the legal basis for protecting the affected communities in the mining sector, as mandated by Article $28 \mathrm{G}$ Paragraph (1) and Article 28H Paragraph (1) of the 1945 Constitution.
\end{abstract}

KEYWORDS: Transfer of Protection Forest Functions, Mining Impacts.

Submitted: 12/02/2020 Reviewed: 14/02/2020 Accepted: 10/03/2020

Copyright $\odot 2020$ by Author(s)

This work is licensed under a Creative Commons Attribution-ShareAlike 4.0 International License. All writings published in this journal are personal views of the authors and do not represent the views of this journal and the author's affiliated institutions.

* Corresponding authors' e-mail: dtriatmojo2@gmail.com 


\section{INTRODUCTION}

Indonesia is a country that has abundant natural resources, both renewable and non-renewable, as those biological resources and non-biological resources. Indonesia's vast natural wealth should be able to use it for the welfare and prosperity of the Indonesian people and be used for the lives of many people under the 1945 Constitution Article 33 paragraph (3), namely: Earth, Water and the natural resources contained therein are controlled by the state and used for the amount of prosperity of the people.

Utilization of the forest area must be adjusted to its primary function in activities to preserve the environment must have several means, namely Institutional Facilities, funds, and legal facilities. The law has a position and importance in dealing with and solving various problems in the environment and is a juridical basis for implementing state policies that must be implemented by the government. ${ }^{1}$ However, in the context of utilizing forest areas that have been expected by law, it cannot be avoided that violations of the use of forest areas for interests outside the forestry sector. One of them is the Mount (Gunung) Tumpang Pitu forest area, Pesanggaran subdistrict, Banyuwangi district, the forest area is one of the protected forest areas in Indonesia.

The protected forest area itself has the primary function outlined in Law Number 41 of 1999 as a life buffer to regulate water management, prevent flooding, control erosion, prevent seawater intrusion, and maintain soil fertility. Like the other main functions of the protected forest, Gunung Tumpang Pitu Protection Forest also has a primary function similar to the passage of time in the forest area found in the soil contains precious metals in the form of gold and copper. So that makes the surrounding community anxious about environmental damage if mining activities are carried out. The benefits of mining activities in Indonesia, where the management of mineral and coal resources can provide benefits for the welfare of the community at large, are expected by law to ensure the effectiveness of the implementation

1 Joni H. 2016, Tindak Pidana Lingkungan Hidup. Pustaka Pelajar, at 2. 
and control of mining businesses in a practical, productive, competitive manner. The key to the success of mining development does not only depend on the amount of wealth or potential of its mineral resources but is determined by political stability, business climate, and success in implementing mining business activities depends on legal certainty, this legal certainty is related to certainty about rights and obligations, especially from the holders IUP and IUPK. ${ }^{2}$

\section{PROTECTED FORESTS TO BECOME OPEN MINING LAND}

Forests are an invaluable national treasure so that the rights of the state to forests and their products need to be protected, maintained, and protected. The forest has a crucial position and role in supporting national development carried out by the central government or regional government as well as the surrounding community in the forest area as explained in Article 33 paragraph (3) of the 1945 Constitution, namely: Earth, Water and The natural resources contained therein are controlled by the state and are used for the greatest prosperity of the people.

In the forestry general plan book, the Minister of Forestry Decree Number 191/Kpts-II/1986 has been stipulated. Explained several activities that support the direction and objectives of forestry development for the national interest, carried out with the primary efforts, as follows:

First. Development Platform for Forestry. The development is part of national development and has a philosophical foundation, constitutional foundation, and conceptual foundation. Aside from the three foundations of forestry development, the operational, technical foundation is also the basis for the implementation of forestry development. Based on the forestry development plan, it is expected that in managing the forest, the exploitation

2 Salim. 2012. Hukum pertambangan mineral dan batubara. Sinar Grafika. at 56. 
and its benefits for the maximum welfare of the people and having the right direction do not violate the law.

Second. Principles, Objectives, and Role of Forestry Development. The principle of forestry development is forest preservation and optimal progressive benefits. This can be classified as forestry development, which is oriented towards the human environment. On that basis and orientation, the objectives are to achieve in forestry development in which it employs the maximum benefits in a versatile and sustainable manner both directly and indirectly.

Understanding protection forests based on Law Number 41 of 1999 Article 1 on Forestry is a forest area that has the primary function as a life support system to regulate water management, prevent flooding, control erosion, preventing seawater intrusion, and maintaining soil fertility. The protected forest area is an area created with the primary function of protecting environmental sustainability, which includes natural resources, consisting of animal and vegetable resources. ${ }^{3}$ The protection function will run optimally if the physical condition of the forest looks good. On the contrary, the protection function is terrible if the condition of the forest is damaged.

Forest management is regulated in Government Regulation No. 6/2007, and Government Regulation No. 3/2008 is intended to cover several aspects of activities, namely forest and preparation plans management protected forest, utilization, and use of protected forest areas, rehabilitation and reclamation of protected forests and nature conservation in protected forests. The importance of the management of areas forest protection, of course, has the following objectives: (a) to improve the function of protected forest on soil, water climate, flora and fauna and historical value; and (b) to maintaining some diversity of plants, animals, types of ecosystems and natural uniqueness. In terms of implementation activities over the function of the protected forest into open-cast mining certainly not under what was planned by

3 Warah Atikah. 2007. Pola Pengelolaan Kawasan Hutan Lindung dan Permasalahannya. at 38. 
Government Regulation No. 6 of 2007 which has the aim to increase the benefits of natural resources and maintain the sustainability of the diversity of flora and fauna contained in the protected forest.

The causes of the management of protected forest areas are very numerous. Several government agencies are responsible for the failure in managing protected forest areas that have been converted into open-pit mining located in the Mount Tumpang Pitu area of Banyuwangi Regency. The area, which was initially a production forest area and protected forest mining activities, began on January 17, 2006, carried out by PT. Indo Multi Niaga (IMN) and in 2012 shares owned by PT. Indo Multi Niaga was sold to PT. Bumi Sukses Indo and PT. Peace of Indo success to date.

The issuance of licenses to carry out mining activities relates to the meaning of Article 33 paragraph (3) of the 1945 Constitution. Likewise, the underlying philosophy of ratification of minerals and coal in Law Number 4 of 2009, based on Article 33 paragraph (3) The 1945 Constitution. This is stated in Law Number 4 of 2009, as minerals and coal as natural resources in the Indonesian mining jurisdiction, constitute the maximum natural resources controlled by the state for the prosperity of the people. However, for the management, it is given to the Government and Regional Government, which also means that the authority to issue mining licenses is in the hands of the Government and Regional Governments under their respective authorities.

According to Article 1 number 7 of Law Number 4 of 2009 concerning Mineral and Coal Mining, Mining Business License (IUP) is an effort to carry out mining carried out by the Minister, Governor, Regent under their authority. The authority to issue IUP can be granted by the multilevel governance. ${ }^{4}$ First, Regent/Mayor authorized to issue mineral and coal mining business licenses requested by the applicant if the mining business permit area (WIUP) is in one regency/city area. Second, the governor has

4 Tri Hayati. 2015, Era baru Hukum Pertambangan Di Bawah Rezim Undang-Undang Nomor 4 Tabun 2009, Yayasan Pustaka Obor Indonesia at 155. 
the authority to grant mineral and coal mining business licenses requested by the applicant if the mining business permit area (WUIP) is located across regencies/cities in one province after obtaining a recommendation from the local regent/mayor under statutory provisions. Third, the Minister has the authority to grant mineral and coal mining business licenses requested by the applicant if the mining business permit area (WIUP) is in the crossprovincial area after obtaining a recommendation from the local governor, regent/mayor under statutory provisions.

Factors for the conversion of protected forest to mining land Companies that work in the mining sector before conducting mining activities conduct a study to explore minerals in the area that will be used as mining to find out how much metal minerals are contained in the Mount Tumpang Pitu area. The research was conducted by the Joint Ore Reserve Committee of the JORC Code and NI 43-101 from Brisbane, Australia, along with consultants Hellman and Schofield. The research results of the JORC Code have resulted in the estimation of the content of precious metals in Mount Tumpang Pitu in the form of gold, silver, and copper.

In research conducted by the JORC Code and NI 43-101, it estimated of every one ton of excavated weight is likely to get as much as $0.2 \%$ gram/ton in copper and $0.40 \%$ gram/ton gold. So in the 499.6 million tonnes of excavated materials, the copper that can be obtained is 8.8 billion pounds, and 14 million ounces of gold excavated from 150 meters to 200 meters below ground level. Moreover, most likely the potential for metal ore increases based on geological factors, the estimated value-added stated by JORC Code and NI 43-101 approximately 800 million to 850 million tons of minerals consisting of $0.3 \%-0.4 \%$ copper and $0.4-0,5 \mathrm{gram} / \mathrm{ton}$ of gold the study was conducted in the gold-copper zone in the Mount Tumpang Pitu Area. ${ }^{5}$

5 Phillip L, Hellman. 2010. Phillip L, Hellman.. Tujuh Bukit Project Report On Mineral Resources. at 64. 
The results of research conducted by JORC Code and NI 43-101 were told that the Mount Tumpang Pitu area could produce 143,000 ounces of gold per year to get 1 Ounce of gold ore, a fee of 376 USD would be required. ${ }^{6}$ Over time, the Mount Tumpang Pitu area will likely be able to produce more mineral metals in gold, copper, and silver.

The opinion above is also strengthened by JICA (Japanese International Cooperation Agency) research, which explains that the Mount Tumpang Pitu area is said to have the highest quality rocks that can even exceed the quality of gold in the Batu Hijau Sumbawa area owned by PT. Newmont. The Mount Tumpang Pitu area has the highest quality rocks because it is located in the middle of the Sunda-Banda magmatic arc. ${ }^{7}$

Mining business licenses must be owned by every business actor who will carry out mining activities in Indonesia. In terms of granting permits made by the government to companies that carry out mining activities in the area of Mount Tumpang Pitu. The government has issued permits twice to the company concerned with a letter numbered $188 / 57 / \mathrm{KP} / 429.012 / 2006$ as a permit to review (SKIP) the government provides recommendations for companies to conduct a review in the Gunung Tumpang Pitu area and then one year later in the year 2007 the government issued permits numbered $188 / 05 / \mathrm{KP} / 429.012 / 2007$ to companies that aimed to provide exploration mining permits (IUP).

With the advent of Law Number 4 of 2009 concerning Mineral and Coal Mining, the government renewed the permits that had been previously given to PT. IMN (Indo Multi Niaga). On January 25, 2010, the government renewed the Exploration IUP under 188/9/KEP/429,011/2010 with a duration of 4 years, and in the same year, the government issued a Production

\footnotetext{
Ibid, at 68.

7 Yu Yu Myaing, Arifudin Idrus, Anastasia Titisari. 2018. Fluid Inclusion Study Of The Tumpang Pitu High Sulfidation Ephitermal Gold Deposit In Banyuwangi District, East Java, Indonesia at 9.
} 
Operation IUP number 188/10/KEP/429.011/2010. The permit has a duration of up to 20 years. ${ }^{8}$

Mining activities carried out by PT. The IMN from 2006 to 2012 was carried out in the area of the Mountain Tumpang Pitu area of 6623.45 hectares as an Exploration site, and the government approved the location of the production operations area of 4998 hectares in total, all mining areas in the Mount Tumpang Pitu area of around 11,621.45 hectares ${ }^{9}$ In 2012 PT. IMN transferred its shares to PT. BSI (Bumi Sukses Indo) which in Act Number 4 of 2009 in Article 93 explains that IUP and IUPK holders may not transfer their IUP and IUPk to other parties. Also, transfer of ownership and/or shares on the Indonesian stock exchange can only be done after conducting certain stages of exploration activities. Transfer of ownership and/or shares as referred to in paragraph (2) can only be done with the following conditions: (a) must notify the Minister, Governor, and Regent/Mayor by their authority; (b) as long as it does not conflict with the provisions of the legislation.

The government approved the transfer proposed by PT. IMN to PT Bumi Sukses Indo with Decree number 545/764/429,108/2012 issued on December 6, 2012, until now, the Gunung Tumpang Pitu mine owner is controlled by PT. Bumi Sukses Indo. If seen from Article 93 of Law Number 4 of 2009 it is stated that the holders of IUP and IUPK cannot be transferred to other parties, then the decree issued by the government has irregularities, and the government can be sued to PTUN because it has issued a decision letter that is not under the law.

Transfer of ownership of a mining company to PT. BSI in 2012 became a breath of fresh air for the ongoing mining activities and to launch mining activities in the area of Mount Tumpang Pitu in the production forest area of 11,621.45 hectares. It includes the addition of land for mining in the protected forest area so that it can proceed according to its plan. PT. BSI

$8 \quad$ S. Phillip L, Hellman. Op.cit at 12.

Ibid, at 11. 
which applied to the Banyuwangi Government to reduce the status of protected forest to production forest. Banyuwangi Regent Abdullah Azwar Anas responded to the request submitted by PT BSI by issuing letternumber 522/635/429/108/2012 dated October 10, 2012, which was proposed to the Ministry of Forestry by requesting the decline in the status of protected forest to production forest of 9,743 hectares in 2013. The Ministry of Forestry issued a decree number SK 826/Menhut-II/2013 dated November 19, 2013, signed by Zulkifli Hasan agreed that the decline in the status of protected forest to production forest was only 1,942 hectares.

The conversion of the function of protected forest to mining is contrary to Law No. 41 of 1999 concerning Forestry Article 38 paragraph (4), which states that protected forest areas are prohibited from mining with open mining patterns. The purpose of the application submitted by PT. BSI is clear to facilitate activities mining in protected forest areas so as not to conflict with laws forestry, but the Ministry of Forestry's decision to convert protected forests into production forests that will be used for mining with open patterns has been under Law No. 41 of 1999. Based on Law Number 41 of 1999, Article 19 explains that the government determines changes in the designation and function of forest areas based on the results of integrated research. Changes in the designation of forest areas, as referred to in paragraph (1), which have significant impacts and broad and strategic value, are determined by the government to approve the House of Representatives. Government Regulation shall regulate provisions regarding the procedure for changing the designation of the forest area and changing the function of the forest area as referred to in paragraph (1) and paragraph (2).

If it is seen based on Article 19 of the Forestry Law above, the government can change the function of the forest area, but the government cannot easily change its function. Changes in forest areas carried out by the government must have sufficient consideration in providing decisions concerning the lives of many people.

Factors underlying the protection forest was conversion into production forest for activities mining in the area of Mount Tumpang Pitu. The 
activities are mining prohibited carried out on protected forests with an open mining pattern and mineral wealth contained in Mount Tumpang Pitu that can grow the economy of the region, especially and nationally as a whole general. The Government of Banyuwangi Regency, in terms of mining business in the area of Mount Tumpang Pitu has a role. The regional government generates the profit generated by the mining business by providing what percentage of income each year to the Banyuwangi Regency government, but the method proposed by PT. BSI to the Banyuwangi local government with the method golden share. The method is a golden share that companies give a few percents of shares owned to the regional government that aims to develop the regional economy. With this method the government will benefit significantly from mining results carried out in the area Tumpang Pitu mountain, the method carried out by the Banyuwangi government is the first in Indonesia. ${ }^{10}$

According to the Regent of Banyuwangi, Abdullah Azwar Anas the existence of mining in the Banyuwangi Regency has provided enormous benefits for the Banyuwangi community. The shares owned by the regional government increased by tens of fold, the amount obtained by the Banyuwangi government from 229 million shares owned by the local government continues to increase in value, which initially only received IDR 20 Billion and now is IDR 580 Billion. The revenue goes directly to the Banyuwangi regional treasury. ${ }^{11}$

The mineral wealth factor contained in the Mount Tumpang Pitu area which can produce 143,000 ounces of gold per year and the Golden Share that has been promised to the government especially the regional government is undoubtedly a consideration, in this case, the Ministry of Forestry to change the function of protected forest areas into production forests for mining use with the open method. The government should consider the adverse effects

10 Tingkatkan Kualitas Program CSR, BSI Tandatangani MoU Bersama Bupati Banyuwangi. https://bumisuksesindo.com/berita/improving-csr-program-qualitybsi-signs-mou-with-banyuwangi-regent (accessed on November 212018 at 16.55 WIB)

11 Ibid. 
of turning protected forests into production forests for mining use before reducing the status of protected forests to production forests.

Mount Tumpang Pitu protected forest area, which has a very abundant mineral wealth becomes an area that can play an essential role in terms of growth and development in terms of the economy of the Banyuwangi region. Banyuwangi Regency gets results from activities mining in one year as much as IDR 580 Billion goes into the regional treasury which has been explained by the Regent of Banyuwangi to build public facilities in the Regency.

\section{LEGAL PROTECTION FOR COMMUNITIES AROUND THE GOLD MINING ACTIVITIES}

Mining activities have positive and negative impacts on the lives of communities around the mining area and the country's national development. The mining business is a business that utilizes natural resources, including effort exploration, exploitation, and processing. Thus in the mining, business activities are very dependent on natural conditions that are focused on geological processes that have taken place naturally in nature. Therefore, the impact of development in the mining sector can occur on a local or global scale.

Its impact is a change or effect that occurs as a result of an activity, as it is not planned or outside the target. To find out an impact or change that occurs must have comparative material as a reference, one of which is the state before the change occurs. ${ }^{12}$ According to Soemarwoto, the impact is a change that occurs as a result of an activity that is both natural, chemical, physical, and biological that affects the socio-economic community around

12 Ilmi Hakimi. 2015. Dampak kebijakan pertambangan batu bara bagi masyarakat Bengkuring Kelurahan Sempaja Selatan Kecamatan Samarinda Utara. Universitas Mulawarman. at 2. 
him. ${ }^{13}$ The impact can be positive benefits, and can also be negative in the form of risk, both of which can impact the physical and non-physical environment, including the social economy.

Metallic minerals are included in non-renewable natural resources. Metallic minerals have unique properties that a mine can work on; the minerals will not grow or be renewed because its non-nature renewable mining activities will affect the shape of the earth's surface and can damage the environment. Environmental impact, according to Article 1 Number 26 of Law Number 32 of 2009 concerning Environmental Protection and Management, is the effect of changes in the environment caused by a business and/or activity.

Mining activities are considered as a source of environmental degradation. Metal mineral mining will have an impact on the existing environmental conditions that can affect the social life of the community around the mining area, reduce environmental quality and reduce the productivity of the land because it can destroy the substances or minerals contained in the soil. In the case of environmental conditions, the existence of mining activities carried out in exploitation. The exploitation of natural resources or natural resources of the mine will only lead to and support economic growth and lead to environmental issues that will provide the possibility of disasters in the future as well as changes in the shape of a plateau, which can affect environmental quality and can reduce productivity soil because it can destroy substances or minerals contained in the soil. According to Qomariah, the impact caused by mining activities not only causes air pollution which results in deterioration of health but also results in the emergence of a basin surrounded by former quarry that has been mixed with the remnants of the mine (tailings) which in the rainy season the basin will be a lake. Remnants of mining material flow into rivers and cover agricultural land and

13 Teuku Ade Fachlevi. Eka Intan Keumala Putri \& Sahat MH Simanjuntak. 2016. Dampak Dan Evaluasi Kebijakan Pertambangan Batubara Di Kecamatan Mereubo. Bogor Agricultural Institute. at 172. 
plantations, resulting in loss of vegetation (plants) of wildlife populations and declining quality water. ${ }^{14}$

For this reason, mining appears problems with environmental management, in order to maintain ecological functions and maintain existing ecosystems. Communities around the mining area are victims of gold mining activities because they are close to mining activities. Consequently, the community becomes disadvantaged because of the existence of mining business activities, even though the community has the right to live comfortably. All Indonesian people are also entitled to have a good environment, as mandated by Article $28 \mathrm{H}$ paragraph (1) of the 1945 Constitution of the Republic of Indonesia which reads:

"every person has the right to live in physical and spiritual prosperity, live, and obtain a living environment that is good and healthy and has the right to receive health services."

The government must think of solutions that can provide a sense of comfort, security, and prosperity to the people in the mining area. The company that conducts mining has a social responsibility of the mining company (corporate social responsibility) to environmental problems that occur as a result of mining business activities, in general, the principle of CSR (corporate social responsibility)on environmental aspects is closely related to Law Number 32 of 2009 concerning Protection and Environmental Management (UUPPLH), especially regarding the obligation to make an AMDAL. ${ }^{15}$

Therefore the negative impact that is given due to activities mining on the community, especially people who are in the area of the mining area, the government must ensure that mining companies do not litter. Mining business activities become part of the way to bring in foreign exchange because, in its utilization, mining can be exported abroad. Besides, through

14 Risal, Paranoan \& Djaja. 2013. Analisis dampak kebijakan pertambangan terhadap kehidupan sosial ekonomi masyarakat di Kelurahan Makroman. Universitas Mulawarman. at 10.

15 Busyra Azheri, 2016, Prinsip Pengelolaan Mineral dan Batubara, Divisi Buku Perguruan Tinggi PT. Raja Grafindo Persada, at 93. 
foreign investment, the potential of natural resources in developing countries such as Indonesia can provide economic added value for people's welfare. Foreign investment will occur state revenue from the tax and non-tax sector, expansion of employment, transfer of technology, skills, and knowledge, as well as macro-economic growth. The role of foreign investment for national economic development is a measure of the amount that goes into a country. ${ }^{16}$

There are some government's efforts in the optimal use of mining minerals for the present and the future. Mineral resources, as one of the natural wealth owned by the Indonesian people, if appropriately managed, will contribute to the country's economic development. The objectives of mineral and coal management as follows: ${ }^{17}$ (a) mastery of mineral and coal mining as a nonrenewable natural resource is a national wealth controlled by the state for the maximum welfare. The control of minerals and coal by the state is carried out by the government and regional governments; (b) nsuring the effectiveness of the implementation and control of mining business activities in an efficient, effective, and competitive manner; (c) guarantee the benefits of mineral and coal mining in a sustainable and environmentally friendly manner; (d) guarantee the availability of minerals and coal as raw material and as a source of energy for domestic needs; (e) supporting and developing national capabilities to be more able to compete at the national, regional and international levels; (f) increasing the income of local, regional and state communities, as well as creating jobs for the maximum welfare of the people; and $(\mathrm{g})$ ensuring legal certainty in conducting mineral and coal mining business activities.

Mining activities can support the development of a country because it results from the use and management of mining. In its regulation, gold metal mineral mining is regulated in Law Number 4 of 2009 concerning Mineral and Coal Mining. The state controls over minerals as described in Article 4

16 Ahmad Redi. 2014, Hukum Pertambangan, Bekasi Gramata Publishing) at 198.

17 Ibid at 24. 
paragraph (1) of Law Number 4 of 2009 concerning Mineral and Coal Mining which reads:

"minerals and coal as non-renewable natural resources are national assets controlled by the state for an amount of -great prosperity of the people."

Mining activities in the area of Mount Tumpang Pitu protected forest named PT. BSI (Bumi Sukses Indo), which has obtained a permit from the government to carry out mining activities with Exploration IUP number 188/9/KEP/429.011/2010 and Production Operation IUP number 188/9 / KEP/429.011/2010. Activities Mining Conducted by PT. BSI in the area of Gunung Tumpang Pitu covering an area of 6623.45 hectares as an Exploration site and the location of production operations is carried out with an area of 4998 hectares in total, all mining areas in the Mount Tumpang Pitu area are around 11,621.45 hectares. Mining conducted at Mount Tumpang Pitu is adjacent to one of the leading tourist attractions in Banyuwangi, namely the red island coast. Mining conducted at Mount Tumpang Pitu has been running for approximately 18 years. Mining activities carried out by PT. IMN in Mount Tumpang Pitu caused strong reactions from the community at the beginning of the plan to manage natural resource potential in the Banyuwangi Regency. Some people consider Mount Tumpang Pitu, which is close to the high seas, to be a natural wave barrier and a barrier to sea winds because, on June 3, 1994, there was an earthquake and tsunami on the coast of Banyuwangi. The existence of Mount Tumpang Pitu was a barrier to the waves.

During the 18 years of conducting mining activities, activities have had a direct or indirect impact on the area of the Mount Tumpang Pitu environment, communities around the mine, and the Banyuwangi regional government. By taking into account the impact felt by the community around Mount Tumpang Pitu since the mining activity appeared, the initial social impact of the people who no longer lived safely and harmoniously, competed with each other to the point where residents were not harmonious. This is because residents around Mount Tumpang Pitu, who initially worked 
as fishermen and farmers, were turned into miners because they were tempted by the mining products they obtained and the surrounding community invested in exploration to aim for higher income.

At the time, PT. IMN began planning the conflict mining that hit the community in the district of Pesanggaran, especially the Gunung Tumpang Pitu area began to heat because people thought mining exploration by PT. IMN is allowed, while the traditional community is not allowed even if it burns one of the posts owned by PT. IMN, until the corporation has prosecuted some people. However, it is different from the community's condition in Sumber Agung Village, where many migrants choose the location, especially mining employees, so that the surrounding community becomes entrepreneurs and builds boarding houses that are rented out for mining employees. Economic conditions in the Sumber Agung Village area have developed rapidly in line with mining activities.

In 2010 the government granted a Production Operation Mining Business License (IUP) to PT. IMN impacts that are starting to be felt by the community around the mine are environmental impacts due to PT. IMN has conducted mining activities until 2012, the shares of PT. IMN was sold to PT. BSI continues the mining activity process. The mining process carried out at Mount Tumpang Pitu uses an extraction process that is harmful to the environment, namely using mercury metals for the amalgamation process because the costs incurred are relatively low. According to the Minister of the Environment, the mercury content is $0.005 \mathrm{ppm}$. Mercury is one of the causes of global environmental problems because its high toxicity causes several harmful effects on human health, animals, and the environment.

Based on what has been explained in Article 96 letter (e) of Law Number 4 of 2009 concerning Mineral and Coal Mining explains:

"Management of the remaining mine from a mining business activity in the form of solid, liquid, or gas to meet environmental quality standards before being released to environmental media." 
If seen from Article 96 letter (e), the mining company carried out by PT. BSI is not following the Law on Mineral and Coal Mining in terms of doing waste treatment or tailings use for the tailings generated by mining activities containing high levels of mercury. The government has provided quality standard provisions where the lowest levels of mining waste containing 0.031 ppm in liquid waste and the highest are $0.062 \mathrm{ppm}$ in sediment waste.

Waste generated by mining activities in the Gunung Tumpang Pitu area is a severe impact on the environment of the mining area because mining waste is hazardous in the future for community life in the mining area, especially the mining area is very close to the tourist attractions of Pulau Merah beach. In 2016, Pulau Merah Beach was affected by mining activities, which caused the beach to be polluted by mud and the frog river, emptying on the beach carrying material.

Communities around the mining area feel disadvantaged due to the negative impacts generated due to mining activities, even though the community also has the right to live comfortably and is entitled to legal protection. As mandated by Article 28G paragraph (1) of the 1945 Constitution of the Republic of Indonesia which outlines everyone has the right to personal, family, honor, dignity, and property under his authority, and is entitled to a sense of security and protection from the threat of fear of doing or not doing something that is a human right.

All Indonesian people are also entitled to have a good environment, as mandated by Article 28H paragraph (1) of the 1945 Constitution of the Republic of Indonesia which outliness:

"every person has the right to live in physical and spiritual prosperity, to live, and obtain a living environment, good and healthy, and have the right to receive health services."

All Indonesians have the same opportunity before the law. Given protection by law to be able to live comfortably and get a good living environment. Everyone has the right to do this, including the people who live in the mining area, they also have the right to the welfare of their lives and obtain a decent 
place to live with a good environment to continue their lives. Some problems have an impact on the environment due to gold mining business activities in various regions in Indonesia. The Indonesian government makes regulations regarding mining as well as possible to anticipate the existence of things that are not desirable. Community protection is regulated in Article 145 of Law Number 4 of 2009 concerning Mineral and Coal Mining, which outlines that people who are directly negatively affected by mining business activities are entitled to obtain appropriate compensation due to errors in the control of mining activities under statutory provisions invitation. Also, they can file a lawsuit with the court for losses resulting from mining operations that violate the provisions. In addition, provisions concerning community protection as referred to in paragraph (1) shall be determined based on statutory provisions.

The community around the mine plays an essential role in the existence of mining business activities because to carry out a mining activity, especially gold, it must be able to consider the interests and safety of the community around the mining area. Communities around the mine must accept all consequences arising from the existence of mining activities. For that reason, in conducting gold mining activities, mining entrepreneurs must be careful and obey all the rules that have been set. Regulations regarding legal protection for people affected by mining activities have been clearly regulated in Article 145 of Law Number 4 of 2009 concerning Mineral and Coal Mining, which regulates community protection.

The protection of people affected by mining is related to the protection of the environment. One thing is sure to conduct mining activities detrimental to the community in the field of environmental conservation. For this reason, Law Number 23 of 2009 concerning Environmental Protection and Management stipulates that environmental protection and management are systematic and integrated efforts undertaken to preserve environmental functions and prevent environmental pollution and/or damage, which includes planning, utilization, control, maintenance, supervision, and law enforcement. In the case of gold mining business activities while maintaining 
environmental sustainability is the main thing, it is in direct contact with the lives of people who live in the mining area.

\section{CONCLUSION}

Factors underlying the government to change the function of protected forests into production forests that will be used for mining activities is to facilitate the licensing of mining activities carried out on protected forests in conflict with Law No. 41 of 1999 concerning Forestry, and the content of mineral resources in The area of Mount Tumpang Pitu is very abundant. It can produce 143,000 ounces of gold per year by the JORC Code. PT. BSI provides mining revenue sharing to the government using the method Golden Share.

One of the positive impacts of mining that is given directly by mining activities is opening up employment opportunities, can grow the economy of the community around the mine and can help grow the regional and national economy. Positive impacts indirectly can build public facilities for free. The negative impact directly from mining can undoubtedly cause damage to the environment, causing conflict in the surrounding community. The negative impact is indirect, namely the disposal of waste produced can pollute the environment. Legal protection of communities affected by mining is carried out by enforcing Law Number 4 of 2009, Law Number 32 of 2009, Government Regulation Number 23 of 2010.

Suggestions aimed at resolving the above problems are that the central and regional governments are expected to be more careful when supervising mining activities. In practice, several government decisions are still in conflict with Law Number 41 of 1999 concerning Forestry concerning the conversion of protected forest as well as supervision of the impact of mining activities so that conflicts do not occur to the community, due to the management of waste containing mercury with high levels that are not under Article 96 letter (e) of Law Number 4 of 2009. 


\section{REFERENCES}

Joni H. 2016, EnvironmentalCriminal.Student Library.

Salim. 2012. Mineral and coal mining law. Sinar Grafika.

Tri Hayati, 2015, New Era of Mining Law Under the Regime of Law Number 4 of 2009, Indonesian Pustaka Obor Foundation

Busyra Azheri, 2016, Principles of Mineral and Coal Management, PT. Raja Grafindo Persada.

Warah Atikah. Pattern of Management of Protected Forest Areas and Their Problems. 2007.

Phillip L, Hellman. Tujuh Bukit Project Report On Mineral Resources. 2010.

Yu Yu Myaing, Arifudin Idrus, Anastasia Titisari. Fluid Inclusion Study Of The Overlapping High Sulfidation Ephithermal Gold Deposit In Banyuwangi District, East Java, Indonesia.2018

Ilmi Hakimi, Impact of coal mining policy for the community of Bengkuring Selatan Sempaja Village, North Samarinda District, (2015) Pap Mhs Polit Univ Mulawarman.

Teuku Ade Fachlevi, Eka Intan Keumala Putri \& Sahat MH Simanjuntak, Impact and Evaluation of Coal Mining Policy in Mereubo District, 2016.

Semuel Risal, DB Paranoan \& Suarta Djaja, Analysis of the impact of mining policies on the socio-economic life of the community in Makroman Village, 2013, 1: 1 EJ Adm Reform.

Sukriyah Kustanti Moerad, Endang Susilowati, Windiani. Mapping of Potential and Economic Impacts of Communities in the Bukit Tumpang Pitu Banyuwangi Mining Area. November 10 Institute of Technology.

https://bumisuksesindo.com/berita/improving-csr-program-quality-bsisigns-mou-with-banyuwangi-regent. 